ks. Janusz Bujak

\title{
Łaska i natura w Maryi jako Niepokalanym Poczęciu
}

\section{Wprowadzenie}

Niniejszy artykuł podejmuje temat relacji łaski i natury w Maryi zachowanej od grzechu pierworodnego i winy osobistej. Mówiąc o naturze, mamy na myśli człowieczeństwo Maryi (dusza i ciało), łaska natomiast to dar komunii z Bogiem, którym została Ona obdarzona w momencie poczęcia w łonie matki. Inaczej mówiąc, chodzi o osobę Maryi w jej relacji do Boga. Zagadnienie relacji łaski i natury Niepokalanie Poczętej związane jest ze stworzeniem człowieka jako imago Dei, na obraz i podobieństwo Boga, z utratą podobieństwa w wyniku grzechu pierworodnego i odnowieniem go w Maryi jako pierwszej spośród odkupionych przez Chrystusa.

W artykule zostanie ukazany rozwój wiary Kościoła w Niepokalane Poczęcie Maryi, jego biblijny fundament oraz owoce łaski zachowania od grzechu pierworodnego w relacji do Osób Trójcy Świętej i wierzących w Chrystusa.

\section{Dojrzewanie Kościoła do wiary w Niepokalane Poczęcie}

„Łaską bowiem jesteście zbawieni przez wiarę. A to pochodzi nie od was, lecz jest darem Boga: nie z uczynków, aby się nikt 
nie chlubił" (Ef 2,8-9). Słowa św. Pawła zrealizowały się po raz pierwszy w historii zbawienia w osobie Maryi. Potwierdza to definicja dogmatyczna o Niepokalanym Poczęciu Najświętszej Maryi Panny ogłoszona przez papieża Piusa IX 8 grudnia 1854 roku bullą Ineffabilis Deus ${ }^{1}$.

Jak zauważa Stefano De Fiores, ogłoszenie dogmatu to efekt współdziałania Ludu Bożego, teologów i Magisterium Kościoła, przy czym główną rolę odegrał Lud Boży, kierując się „zmysłem wiary"2. Wiara w Niepokalane Poczęcie zrodziła się bowiem w nim, a ten niemal instynktownie pojął, że jakikolwiek grzech byłby nie do pogodzenia ze świętością Matki Bożej. Konieczna jednak była refleksja teologiczna dla wyjaśniania wiary ludu, zharmonizowania jej z danymi pochodzącymi z objawienia, rozwią-

1 Pius IX, List apostolski (bulla) Ineffabilis Deus o Niepokalanym Poczęciu Najświętszej Maryi Panny, Niepokalanów 2003, s. 54-55: „Ku chwale Świętej i Nierozdzielnej Trójcy, ku czci i sławie Bogurodzicy Dziewicy, dla podniesienia wiary katolickiej i dla wzrostu religii chrześcijańskiej powagą Pana naszego Jezusa Chrystusa, świętych Apostołów Piotra i Pawła oraz naszą oświadczamy, stanowimy i wyrokujemy, że od Boga jest objawiona, a przeto przez wszystkich wiernych mocno i stale ma być wiarą wyznawana nauka, według której Najświętsza Dziewica Maryja w pierwszej chwili swego poczęcia za szczególniejszą łaską i przywilejem Boga Wszechmogącego, przez wzgląd na przyszłe zasługi Jezusa Chrystusa Zbawiciela rodzaju ludzkiego zachowana była wolną od wszelkiej zmazy pierworodnej winy"; por. Breviarium Fidei. Wybór doktrynalnych wypowiedzi Kościoła, red. S. Głowa, I. Bieda, Poznań 1988, s. 269, nr 89; A. Jankowski, Bliżej Bogarodzicy. Studia z mariologii biblijnej, Kraków 2005, s. 46-49.

2 Por. S. De Fiores, Immacolata, w: Nuovo Dizionario di mariologia, red. S. de Fiores, S. Meo, Roma 1986, s. 681-682. De Fiores stwierdza, że pierwszym teologiem, który wprost mówi o wyższości wiary Ludu Bożego nad opiniami teologów był Eadmer (†ok. 1134), uczeń św. Anzelma z Canterbury. W dziele pt. Tractatus de conceptione sanctae Mariae przeciwstawia „czystą prostotę" i „pokorną pobożność” ubogich w wiedzę bogatych duchownych i świeckich, którzy walczą ze świętem Poczęcia jako pozbawionym fundamentów. Eadmer opowiada się po stronie ubogich, ponieważ Bóg objawia się pokornym. 
zania trudności teologicznych i kulturowych oraz dostarczania przekonujących argumentów na rzecz Niepokalanego Poczęcia ${ }^{3}$.

Pierwszym teologiem, który w sposób wyraźny uzasadnił Niepokalane Poczęcie Maryi, był bł. Jan Duns Szkot (†1308), który wykazał, że w zbawczym dziele Chrystusa było ono nie wyjątkiem, ale doskonałym przykładem zbawczego działania Jedynego Pośrednika ${ }^{4}$.

Kolejnym czynnikiem, który przyczynił się do rozwoju wiary w Niepokalane Poczęcie Maryi, była postawa papieży, którzy począwszy od Sykstusa IV (†1484) aż do Piusa IX (†1878), bronili wiary w nie $^{5}$.

Zatem w powstaniu, rozwoju i ogłoszeniu prawdy o Niepokalanym Poczęciu Maryi brali udział wszyscy członkowie Kościoła: świeccy, teologowie i biskupi, każdy na swój sposób, podkreśla De Fiores ${ }^{6}$. Potwierdza to również sposób uzasadnienia dogmatu w bulli Ineffabilis Deus, który polega na wyjściu od wiary Ko-

3 Por. S. Langosz, Niepokalane Poczęcie w kontekście nauczania Ojców Kościoła o świętości Maryi (II-IV wiek), w: Tota pulchra es Maria. Materiały z ogólnopolskiego sympozjum mariologicznego z okazji 150 rocznicy ogłoszenia dogmatu o Niepokalanym Poczęciu Matki Bożej. Licheń, 17-20 mają 2004 r., red. J. Kumala MIC, Licheń 2004, s. 43-85; G. Bartosik OFMConv, Pneumahagijny wymiar niepokalanego poczęcia Maryi, w: Tota pulchra es Maria, s. 188-200.

4 Por. S. De Fiores, Immacolata (1986), s. 684-686; S. Cecchin, Uzasadnienie Niepokalanego Poczęcia Najświętszej Maryi Panny według bł. Jana Dunsa Szkota, w: „Złota nić” Niepokalanego Poczęcia w myśli i życiu bł. Jana Dunsa Szkota i św. Maksymiliana Marii Kolbego, red. G.M. Bartosik OFMConv, P. Warchoł OFMConv, Niepokalanów 2015, s. 93-116; L. Scheffczyk, Maryja. Matka i Towarzyszka Chrystusa. Podręcznik teologii, tłum. J. Tumielewicz, Kraków 2004, s. 135-139; J. Bolewski, Miłość i mądrość a Niepokalane Poczęcie, w: „Złota nić” Niepokalanego Poczęcia w myśli i życiu bł. Jana Dunsa Szkota i św. Maksymiliana Marii Kolbego, s. 182-187.

5 Por. S. De Fiores, Immacolata (1986), s. 686-687.

6 Por. tamże, s. 687; Th. A. Thompson, The Immaculate Conception in the Catholic-Protestant Ecumenical Dialogue, „Marian Studies” 55 (2004), s. 246-249. 
ścioła, by w jej świetle przejść do argumentu biblijnego (Protoewangelia, starotestamentalne figury Niepokalanej, wypowiedzi proroków i dwa teksty z Nowego Testamentu: Ave Maria i Magnificat). Bulla wskazuje, że Tradycja Kościoła jest miejscem, w którym dokonuje się interpretacja Pisma Świętego?.

\section{Pismo Święte o zachowaniu Maryi od grzechu pierworodnego}

\subsection{Księga Rodzaju: stworzenie, upadeki zapowiedź Zbawiciela}

Niepokalane Poczęcie Maryi jest ściśle związane ze stworzeniem człowieka i jego upadkiem. Pismo Święte uczy, że człowiek został stworzony przez Boga na Jego obraz i podobieństwo, jako imago Dei (por. Rdz 1,26-27). Człowiek został stworzony do komunii z Bogiem i to powołanie można uznać za pierwszą i podstawową łaskę, otrzymaną wraz z łaską istnienia ${ }^{8}$. Stan „świętości i sprawiedliwości", w którym żyli pierwsi ludzie, jak uczy sobór trydencki ${ }^{9}$, jest tym, co definiuje „raj”, w którym Stwórca umieścił człowieka. Pozostałe dary, którymi go ubogaca, wynikają z pierwszej łaski - zaproszenia do komunii z Bogiem. Oprócz tych darów i łask człowiek został obdarzony również darami pozaprzyrodzonymi: nieśmiertelnością i brakiem pożądliwości, czyli skłonności do złego. Dobra, którymi człowiek cieszył się w raju, wynikały z jego komunii ze Stwórcą; były one zewnętrznym wyrazem łaski, o czym świadczy fakt ich utraty po grzechu pierworodnym ${ }^{10}$.

7 Por. A. Serra, Immacolata, w: Nuovo Dizionario di mariologia, s. 688-689; L. Scheffczyk, Maryja. Matka i Towarzyszka Chrystusa, s. 138.

8 Por. L.F. Ladaria, Antropologia teologica, Casale Monferrato 1995, s. 213.

9 Por. Dokumenty Soborów Powszechnych, t. IV: 1511-1870, oprac. A. Baron, H. Pietras SJ, Kraków 2005, s. 235.

10 Por. L.F. Ladaria, Antropologia teologica, s. 214-223. Jak podkreśla autor, łaska, którą otrzymał człowiek przed upadkiem w grzech pierworodny, 
Z objawienia wiadomo, że Adam otrzymał pierwotną świętość i sprawiedliwość nie tylko dla siebie, ale dla całego rodzaju ludzkiego. Dając posłuch kusicielowi, Adam i Ewa popełniają grzech „osobisty”, który jednak dotyka „natury ludzkiej”, którą przekazują „,w stanie upadku” (Katechizm Kościoła katolickiego [dalej KKK] 404). Chodzi zatem o grzech, który zostaje przekazany przez zrodzenie. Potomstwo Adama otrzymuje naturę ludzką pozbawioną pierwotnej świętości i sprawiedliwości, czyli łaski uświęcającej oraz darów nadprzyrodzonych i pozaprzyrodzonych, które posiadali pierwsi rodzice. $Z$ tego powodu grzech pierworodny jest grzechem szczególnym, ponieważ ,jest grzechem «zaciągniętym», a nie "popełnionym», jest stanem, a nie aktem" (KKK 404).

Bóg jednak nie zapomniał o człowieku, który okazał nieposłuszeństwo Jego nakazom. Już w Księdze Rodzaju mamy zapowiedź zwycięstwa nad szatanem: „Wprowadzam nieprzyjaźń między ciebie a niewiastę, pomiędzy potomstwo twoje a potomstwo jej: ono ugodzi cię w głowę, a ty ugodzisz je w piętę" $(\operatorname{Rdz} 3,15)^{11}$. Kościół odczytał ten tekst jako protoewangeliczną zapowiedź przyjścia Chrystusa i Maryi jako drugiej Ewy - oblubienicy drugiego Adama. Fragment ten mówi o nieprzyjaźni pomiędzy kobietą, która jest figurą Maryi, i wężem, który

była łaską pochodzącą od Chrystusa, ponieważ nie istnieje żadna łaska, która by nie pochodziłaby z Jego wcielenia i misterium paschalnego. Stworzenie istnieje w perspektywie wcielenia Syna Bożego, dzięki któremu osiąga swoją pełnię. W artykule nie będziemy się zajmowali kwestią naprzyrodzoności, relacji „natury czystej” (natura pura) i łaski. $\mathrm{Na}$ ten temat dyskutowany zwłaszcza w drugiej połowie XX wieku por. F. Blachnicki, Stosunek natury do łaski jako problem teologiczno-pastoralny, „Collectanea Theologica” 36 (1966) 1-4, s. 128-156; R. Kostecki, Stosunek natury do łaski, „Studia Theologica Varsaviensia” 8 (1970) 2, s. 93-108; L.F. Ladaria, Wprowadzenie do antropologii teologicznej, tłum. A. Baron, Kraków 1997, s. 75-82.

${ }_{11}$ Cytaty biblijne za: Biblia Tysiąclecia. Pismo Święte Starego i Nowego Testamentu, wyd. 5, Poznań 2003. 
jest figurą szatana. Pomiędzy nimi nie ma żadnej wspólnoty, zatem w Maryi nie ma śladu zmazy grzechu pierworodnego ${ }^{12}$. Leo Scheffczyk podkreśla, że fragment ten wskazuje na negatywny aspekt prawdy o Niepokalanym Poczęciu, o nieprzyjaźni pomiędzy Maryją a szatanem, która to nieprzyjaźń potwierdza, że „Matka Boża zawsze znajdowała się ponad tymi grzesznymi siłami, które nigdy nie miały nad Nią władzy"13.

Stworzenie człowieka znajduje swoje spełnienie w Jezusie Chrystusie - nowym Adamie, który począł się z Ducha Świętego w łonie Maryi. W Nim człowiek dostępuje łaski odnowienia podobieństwa do Boga przez uwolnienie od zmazy grzechu pierworodnego. Pierwszą z ludzi, która została obdarzona tą łaską, była Maryja z Nazaretu. Wszyscy inni ludzie dostępują obmycia z grzechu pierworodnego w sakramencie chrztu świętego ${ }^{14}$.

\subsection{Nowy Testament: Niepokalana na wzór Kościoła}

Według św. Tomasza z Akwinu człowiek może uczestniczyć w życiu Bożym na trzech stopniach: imago creationis, który polega na naturalnej zdolności poznania Boga i kochania Go i który przynależy wszystkim ludziom $z$ natury nawet po grzechu pierworodnym; imago recreationis to uczestnictwo Stwórcy w życiu czło-

12 Por. R. Coggi, Trattato di mariologia. I misteri della fede in Maria, Bologna 2011, s. 160.

13 Por. L. Scheffczyk, Maryja. Matka i Towarzyszka Chrystusa, s. 139; J. Bolewski, W Duchu i Mocy Niepokalanego Poczęcia, Kraków 1998, s. 37, pytał, jak należy rozumieć $\mathrm{Rdz}$ 3,15: „ono ugodzi cię w głowę, a ty ugodzisz je w piętę”. Ona czy ono ugodzi węża w głowę? Raczej „ono”, potomstwo, Chrystus. „Jednak szczególnym znakiem Jego zwycięstwa nad złem jest Maryja, właśnie w swym początku, który nie był skażony przez grzech pierworodny. Dlatego zapowiedź Księgi Rodzaju mogła być w tradycji łączona z Maryją i Jej Niepokalanym Poczęciem, jak na to wskazuje najbardziej znany znak tej tajemnicy: Maryja depcząca głowę węża".

14 Por. R. Coggi, Trattato di mariologia, s. 159. 
wieka przez łaskę; trzeci rodzaj obecności Boga w duszy ludzkiej dotyczy zbawionych w niebie - to imago similitudinis ${ }^{15}$.

Maryja dzięki zachowaniu od grzechu pierworodnego przez całe życie trwała w łasce uświęcającej, nosiła w duszy imago recreationis. Wskazują na to teksty biblijne traktowane jako loci classici w argumentacji za Niepokalanym Poczęciem.

Pierwszy fragment traktowany przez Kościół jako bezpośredni dowód na Niepokalane Poczęcie, jako potwierdzenie całkowitej pełni łaski od pierwszego momentu życia Maryi aż do jego zakończenia, to słowa archanioła Gabriela skierowane do Niej w momencie zwiastowania: „Bądź pozdrowiona, łaski pełna, Pan z Tobą” (Łk 1,28). Zwrot „łaski pełna” w języku greckim brzmi kecharitomene i oznacza ,jednorazową, dokonaną w przeszłości czynność, związaną z udzieleniem łaski i obdarzeniem łaską w taki sposób, że powoduje ona istotową zmianę w przedmiocie działania”, wyjaśnia Mariusz Rosik ${ }^{16}$. „Biorąc pod uwagę trwałość tego stanu, można przyjąć, że uświęcenie to jest doskonałe, a skoro tak, to znaczy, że musiało się dokonać jeszcze przed poczęciem Maryi i polegało na zachowaniu Jej od grzechu pierworodnego, a w konsekwencji także od grzechów aktualnych"17.

Również makaryzmy wypowiedziane przez Elżbietę w stosunku do Maryi: „Błogosławionaś ty między niewiastami i błogosławiony jest owoc Twojego łona” (Łk 1,42) i „Błogosławiona [jest], która uwierzyła, że spełnią się słowa powiedziane Jej od

15 Por. F. Conigliaro, L'uomo imago Dei fine della creazione. Antropologia di Tommaso d'Aquino, „Ho Theologos” 5 (1978) 18, s. 86; B. Mondin, L'uomo secondo il disegno di Dio. Trattato di antropologia teologica, Bologna 1992, s. 164.

${ }^{16}$ M. Rosik, Niepokalana - pełna łaski. Przyczynek do interpretacji terminu „Kecharitomene” (Łk 1,28), w: Misterium Niepokalanego Poczęcia Najświętszej Maryi Panny. Materiały sesji naukowej na Papieskim Wydziale Teologicznym we Wrocławiu z okazji ogłoszenia dogmatu o Niepokalanym Poczęciu Najświętszej Maryi Panny. 16 XII 2004, red. ks. W. Wołyniec, Wrocław 2004, s. 10.

17 Tamże, s. 12; por. R. Coggi, Trattato di mariologia, s. 160. 
Pana" (Łk 1,45), zwłaszcza pierwszy z nich, potwierdzają, że jest Ona Niepokalanie Poczęta ${ }^{18}$.

Kolejnym fragmentem, który pośrednio mówi o Niepokalanym Poczęciu Maryi, jest eulogia z Listu do Efezjan 1,3-14. Szczególnie istotny jest tekst z Ef 1,4-6: „W Nim bowiem wybrał nas przed założeniem świata, abyśmy byli święci i nieskalani przed Jego obliczem. Z miłości przeznaczył nas dla siebie jako przybranych synów przez Jezusa Chrystusa, według postanowienia swej woli, ku chwale majestatu swej łaski, którą obdarzył nas w Umiłowanym".

Jacek Bolewski zauważa, że Hymn z Listu do Efezjan mówi nam, że Boży plan zbawienia był podjęty jeszcze „przed założeniem świata”, więc i przed grzechem, który planu tego nie zniweczył: „Grzech jest późniejszy, niezdolny tej pierwotnej dobroci zniweczyć. O tym mówi obecnie Maryjny znak niepokalanego poczęcia"19.

Drugi fragment Listu do Efezjan mówi o typologicznym wymiarze Niepokalanego Poczęcia. Typem Maryi wolnej od grzechu pierworodnego jest bowiem Kościół opisany w Ef 5,27 jako święty”, „bez skazy”, „chwalebny”, „nie mający skazy czy zmarszczki, czy czegoś podobnego". Niepokalane Poczęcie jest elementem nauczania o Ecclesia Immaculata, o której mówią ojcowie Kościo-

18 Por. S. Harzęga, Nowotestamentalne podstawy dogmatu niepokalanego poczęcia Maryi, w: Tota pulchra es Maria, s. 33-37; M. Rosik, Niepokalana - petna łaski, s. 12-13: „Niepokalane Poczęcie to łaska uprzednia, zachowująca. Wskazuje na to participium perfecti passivi słowa kecharitomene, które można tłumaczyć jako «wypełniona łaską» (Łk 1,28), zaś w Łk 1,30: «znalazłaś bowiem łaskę u Pana» mamy indicativus aoristi, który oznacza, że "wypełnienie łaską» dokonało się jednorazowo w przeszłości i czynność ta jest definitywnie zakończona. Maryja uzyskała pełnię łaski nie w chwili poczęcia Jezusa, lecz wcześniej. To właśnie owa pełnia łask stała się podstawą przywileju Bożego macierzyństwa Maryi. Takie właśnie użycie form gramatycznych stoi w pełnej harmonii z ideą praeredemptio".

19 Por. J. Bolewski, W Duchu i Mocy Niepokalanego Poczęcia, s. 37. 
ła. „Nauczanie o Niepokalanym Poczęciu, jak i cała późniejsza mariologia, jest tu antycypowane jako eklezjologia. Obraz Kościoła jako dziewicy - matki zostanie drugorzędnie odniesiony do Maryi, a nie na odwrót", pisze Joseph Ratzinger. Niepokalane Poczęcie potwierdza, że „istnieje Kościół święty - jako osoba i w osobie”, jest ono „wyrazem pewności zbawienia Kościoła”, dokonania się przymierza Izraela z Bogiem, dowodem na to, że „łaska Boża działała w sposób wystarczający, by wzbudzić odpowiedź, że łaska i wolność" nie wykluczają się, ale warunkują i zakładają ${ }^{20}$.

Teksty biblijne potwierdzają zatem dogmatyczną prawdę o zachowaniu Maryi od grzechu pierworodnego, jednak trzeba pamiętać, że dogmatu nie da się udowodnić za pomocą samej tylko metody historyczno-krytycznej, „gdyż metoda ta nie obejmuje analizy wpływu, jaki tekst biblijny wywierał na gminę chrześcijańską"21. Dopiero świadomość Ludu Bożego i teologia, wspierane przez magisterium papieży i soborów, odkryły, że tym samym Maryja jest pierwszą spośród odkupionych przez

20 Por. J. Ratzinger, Wzniosła Córa Syjonu. Rozważania mariologiczne, tłum. J. Królikowski, Poznań 2002, s. 45, 47; A. Langella, Peccato originale e dogma dell'Immacolata Concezione. La proposta di Gerhard Lohfink e Ludwig Weimer, „Asprenas” 62 (2015), s. 115. Langella w artykule omawia książkę G. Lohfinka i L. Weimera Maryja - nie bez Izraela. Nowe spojrzenie na naukę o Niepokalanym Poczęciu, tłum. E. Pieciul-Kamińska, Poznań 2010. Langella stwierdza, że niemieccy teologowie ukazują chrześcijańską świadomość relacji Maryi i Izraela w długiej serii świadectw - od ojców Kościoła przez autorów średniowiecznych aż po Sobór Watykański II i autorów posoborowych. Wszyscy oni zgodnie określają Maryję jako prawdziwego Izraela, wypełnienie obietnic Starego Przymierza, personifikację „reszty Izraela”. Podkreślają oni, że osoba Matki Jezusa nie może być zrozumiana bez związku z ludem, do którego należy: „nie bez Izraela”! Właśnie wychodząc z tego założenia, autorzy książki podkreślają, że tradycja chrześcijańska odczytuje niepokalaność Maryi jako konsekwencję niepokalaności Kościoła, potwierdzonej w tekstach biblijnych (np. 2 Kor 11,2; Ef 1,3; 5,27).

${ }^{21}$ L. Scheffczyk, Maryja. Matka i Towarzyszka Chrystusa, s. 139. 
Chrystusa ${ }^{22}$. W Niej oglądamy człowieka, który został stworzony w pełni na obraz i podobieństwo Boga i Chrystusa - imago Dei i imago Christi. Podobieństwo to oznacza życie w pełnej komunii z Bogiem Trójjedynym.

\section{Relacje Maryi Niepokalanie Poczętej do Osób Trójcy Świętej}

Po ludzkiej duszy Jezusa Chrystusa o absolutnie niezrównanej doskonałości, świętości i blasku dusza Niepokalanie Poczętej lśni największą czystością i pięknem w całym stworzeniu, podkreśla Deyanira Flores ${ }^{23}$. Battista Mondin OP wyjaśnia, że Maryja, „pełna łaski”, jest jednocześnie „ułaskawiona” (od grzechu pierworodnego) i wypełniona łaską (pełna świętości). W Konstytucji dogmatycznej o Kościele Lumen gentium (dalej LG) czytamy, że Maryja jest „Rodzicielką Syna Bożego, a przez to najbardziej umiłowaną córą Ojca i świętym przybytkiem Ducha Świętego, dzięki zaś temu darowi szczególnej łaski góruje wielce nad wszystkimi innymi stworzeniami zarówno ziemskimi, jak niebieskimi" (LG 53) ${ }^{24}$.

22 Por. tamże. Na stronie 140 można przeczytać, że współczesna egzegeza, posługując się metodami filologicznymi, „nie jest w stanie powiedzieć, czy w tym fragmencie chodzi o potwierdzenie całkowitego uwolnienia Maryi od grzechu już na samym początku Jej ziemskiej egzystencji; mimo to przyznaje tym słowom pozdrowienia głębszy sens".

${ }^{23}$ Por. D. Flores, Mary, the Virgin "Completely and Permanently Transformed by God's Grace": The Meaning and Implications of Luke 1:28 and the Dogma of the Immaculate Conception for Mary's Spiritual Life, „Marian Studies” 55 (2004), s. 47, 73.

24 Por. B. Mondin, Maria Madre della Chiesa. Piccolo trattato di mariologia, Roma 2007, s. 96. 


\subsection{Maryja w Bożym planie zbawienia}

Bóg obdarzył Maryję miłością większą niż inne stworzenia i obdarzył swymi darami, dzięki którym była wolna od jakiejkolwiek skazy grzechu ${ }^{25}$. Maryja po Bogu jaśniała największą świętością, dzięki czemu odniosła Ona zwycięstwo nad starodawnym wężem, czytamy w bulli Ineffabilis Deus ${ }^{26}$. Niepokalane Poczęcie jest zatem częścią Bożego planu zbawienia. Wszyscy, również Maryja, zostali usprawiedliwieni przez łaskę: „dostępują usprawiedliwienia darmo, z Jego łaski, przez odkupienie, które jest w Chrystusie Jezusie" (Rz 3,24). Zachowanie Maryi od grzechu i pełnia łaski nie są skutkiem Jej wiary, wolności czy dobrych czynów, ale wynikają ze zbawczej woli Ojca, który odwiecznie decyduje o miłości do ludzi poza ich grzechem i zasługą. Niepokalane Poczęcie objawia absolutną inicjatywę zbawczą Stwórcy i oznacza, że od zarania swego istnienia Maryja była otoczona zbawczą i uświęcającą miłością Boga, podkreśla Stefano De Fiores ${ }^{27}$.

25 Por. Pius IX, List apostolski (bulla) Ineffabilis Deus, s. 1-2.

Por. tamże, s. 11-12: „Niewypowiedziany Bóg [...] gdy przed wiekami przewidział najsmutniejszy upadek całego rodzaju ludzkiego w grzech odziedziczony po przestępstwie Adama, w zakrytej od wieków tajemnicy postanowił pierwsze dzieło swej dobroci urzeczywistnić jeszcze bardziej tajemniczym cudem przez Wcielenie Słowa [...]. Na samym tedy początku i przed wszystkimi wiekami wybrał Bóg i swemu Synowi Matkę, z której wcielony po szczęśliwym wypełnieniu się czasów miał się narodzić". Por. S. De Fiores, Immacolata, w: Maria. Nuovissimo Dizionario, t. 1, Bologna 2006, s. 866-867; L. Scheffczyk, Maryja. Matka i Towarzyszka Chrystusa, s. 134-135: „Bóg już od zarania czasu przeznaczył Maryi rolę u boku Chrystusa oraz wybrał Ją na Jego Matkę i towarzyszkę". Boży plan zbawienia nie zawiera przypadków. „Jest zatem zrozumiałe, że realizacja tego planu rozpoczęła się od wydarzenia, które w swojej wymowie nawiązuje do samych początków ludzkości. Chodzi w tym wypadku o uwolnienie Maryi od grzechu pierworodnego [...] w momencie poczęcia Jej przez matkę", które Kościół nazwał Niepokalanym Poczęciem. 


\subsection{Maryja - doskonały obraz Syna Bożego}

Maryję można zrozumieć, wyłącznie wychodząc od Chrystusa, który w misterium paschalnym przyniósł pojednanie z Bogiem całej ludzkości (2 Kor 5,18-21), a zatem również swojej Matce. Maryja została zbawiona w najwyższy sposób (sublimiori modo redempta) w perspektywie zasług swojego Syna, dlatego Niepokalane Poczęcie w żaden sposób nie zaprzecza powszechnej konieczności zbawienia przez Chrystusa, a raczej zakłada, że Maryja „złączona jest ze wszystkimi ludźmi, którzy mają być zbawieni, pochodzeniem z rodu Adama" (LG 53) i otrzymała w swojej niezdolności do samozbawienia zbawczą łaskę większą niż można to sobie wyobrazić. To właśnie wyraził Dunst Szkot w argumencie o doskonałym Pośredniku, w którym ukazuje moc zbawczą Chrystusa, przez którą raczej zapobiega grzechowi niż go zmazuje po jego dokonaniu ${ }^{28}$.

Włoska teolog Ina Siviglia zauważa, że w Matce Chrystusa Duch Święty, antycypując skutki zbawienia, kształtuje obraz i podobieństwo z Synem - prawdziwym Obrazem - w jego najwyższej formie ${ }^{29}$. Stanisław Budzik podkreśla, że w Maryi ludzkość widzi człowieka takim, jakim zapragnął go Bóg w pierwszym momencie stworzenia. Niepokalane Poczęcie Maryi, Jej wolność od jakiegokolwiek grzechu od samego początku swego istnienia, ma związek nie tylko z wcieleniem Syna Bożego, ale także ze zbawieniem całej ludzkości, Maryja jest bowiem „pierwszą przedstawicielką nowej ludzkości spod znaku stwórczego planu Boga"30. Również Scheffczyk podkreśla, że zachowanie

28 Por. S. De Fiores, Immacolata (2006), s. 867-868; J. Bujak, Trynitarne i antropologiczne aspekty mariologii włoskiej po Soborze Watykańskim II, Szczecin 2019, s. 161-162.

29 Por. I. Siviglia, Antropologia teologica in dialogo, Bologna 2007, s. 156$-157$.

30 Por. S. Budzik, Maryja w tajemnicy Chrystusa i Kościoła, Tarnów 1995, s. 106-107; W. Życiński, Jedność w wielości. Perspektywy mariologii ekumenicznej, Kraków 1992, s. 166; J. Bujak, Ekumeniczny wymiar antropo- 
Maryi od grzechu pierworodnego i uświęcenie łaską Ducha Świętego wyjaśnia, czym jest odkupienie: „Jest to przywrócenie od nowa i w sposób wyższy pierwotnie urzeczywistnionej przez Stwórcę idei człowieka jako nieskażonego obrazu Boga, znajdującej swój sens w radykalnym, nie znającym egoistycznych odchyleń zwróceniu się ku Bogu"31. Po upadku pierwszych ludzi nikt nie jest w stanie żyć w całkowitym oddaniu się Bogu; dotyczy to również człowieka ochrzczonego. Jedynie w Maryi to „załamanie, skrzywienie i spaczenie ludzkiej egzystencji miało zostać w sposób jedyny przezwyciężone - dla chwały Odkupiciela i jako przykład dla odkupionych. Egzystencja Maryi, człowieka nigdy nie zranionego grzechem i żyjącego z głębi pełnej wspólnoty z Bogiem, mówi nam bowiem o naszym własnym powołaniu. I nie tylko mówi, ale pociąga nas przemożną siłą" ${ }^{2}$.

Maryja już w czasie swego ziemskiego życia była w pełni podobna do swego Syna, ukształtowana na Jego „obraz i podobieństwo", co uwidaczniało się w całym Jej życiu, przede wszystkim zaś w Jej postawie „kenotycznej”. Maryja określa siebie dwukrotnie jako „służebnicę Pańską", w momencie zwiastowania (Łk 1,38) i w hymnie Magnificat (Łk 1,48). W ten sposób antycypuje Ona postawę Chrystusa, który również powie o sobie, że „nie przyszedł, aby Mu służono, lecz żeby służyć” (Mk 10,45), a św. Paweł w Liście do Filipian napisze, że „ogołocił samego

logii teologicznej na przykładzie wybranych aspektów mariologii, w: Matka Jezusa w dialogu ekumenicznym. Implikacje teologiczno-filozoficzne, red. B. Kochaniewicz, Poznań 2012 (Studia Theologiae Fundamentalis, 4), s. 71-74.

31 Cześć Maryi dzisiaj. Propozycje pastoralne, red. W. Beinert, Warszawa 1992, s. 122; por. J. Królikowski, K. Kupiec, Matka Zbawiciela. Mariologia, cz. II, Tarnów 2000, s. 109-111; R. Laurentin, Matka Pana. Krótki traktat teologii maryjnej. Wydanie integralne, tłum. Z. Proczek, Warszawa 1989, s. 77, 91-92, 108-109.

${ }^{32}$ Cześć Maryi dzisiaj. Propozycje pastoralne, s. 122; por. L. Scheffczyk, Maryja. Matka i Towarzyszka Chrystusa, s. 142. 
siebie, przyjąwszy postać sługi” (Flp 2,7) ${ }^{33}$. Ten „kenotyczny” wymiar życia Maryi osiągnie swój szczyt na Golgocie, u stóp krzyża Chrystusa. Siviglia podkreśla, że droga wyznaczona człowiekowi przez Chrystusa, Człowieka doskonałego, doskonałego Obrazu Boga, wyrażona w Liście do Filipian 2,6-11, jest drogą, którą musi przejść każdy, kto chce się upodobnić do obrazu Syna ${ }^{34}$.

\subsection{Maryja - „wcielenie” Ducha Świętego}

Bulla Ineffabilis Deus ukazuje ścisły związek Maryi i Ducha Świętego, który „chciał i sprawił to, że z Dziewicy począł się i narodził ten, od którego On sam pochodzi" ${ }^{35}$. Następnie dokument bł. Piusa IX przedstawia uświęcające działanie Ducha Świętego w Maryi w sposób negatywny i pozytywny. Czytamy, że Maryję „uprzedzająca łaska Ducha Świętego zachowała od grzechu pierworodnego"36, ale również, że Duch Święty przyozdobił Ją wszystkimi darami i łaskami ${ }^{37}$, ukształtował i przyozdobił jako przybytek Boga ${ }^{38}$.

Po tej linii idzie również konstytucja soborowa Lumen gentium, która za wschodnimi ojcami Kościoła przedstawia Maryję jako „wolną od wszelkiej zmazy grzechowej”, ale również „jakby utworzoną przez Ducha Świętego i ukształtowaną jako nowe stworzenie" (LG 56) ${ }^{39}$. Tradycja nadała Maryi tytuły wyrażające

${ }_{33}$ Por. Jan Paweł II, Encyklika Redemptoris Mater nr 13, 26, 28, 38-41.

34 Por. I. Siviglia, Antropologia teologica in dialogo, s. 159; na temat ubóstwa i uniżenia się Maryi, na poziomie realnym i duchowym por. S. de Fiores, Maria Madre di Gesú. Sintesi stolico-salvifica, Bologna 1992, s. 218-219; S. Budzik, Maryja w tajemnicy Chrystusa i Kościoła, s. 150-152; J. Bujak, Uczestnictwo Maryi w kenozie i wywyższeniu Chrystusa, „Rocznik Skrzatuski" 1 (2013), s. 13-25.

35 Pius IX, List apostolski (bulla) Ineffabilis Deus, s. 13.

36 Tamże, s. 24.

37 Por. tamże, s. 39, 46.

38 Por. tamże, s. 44.

39 Por. S. De Fiores, Immacolata (2006), s. 869. 
Jej ścisłą relację do Ducha Świętego: „Świątynia lub Przybytek Ducha Świętego" lub nawet „Oblubienica Ducha Świętego”. Relacja ta jest owocem relacji Maryi z Chrystusem, która zakłada równie głęboki związek z Duchem Świętym, prowadzącym wraz z Chrystusem z woli Ojca dzieło zbawienia ${ }^{40}$. Duch Święty jest u początku życia Maryi (Niepokalane Poczęcie) i u końca (Wieczernik Zielonych Świąt), kiedy prosi Ona Ducha Świętego o napełnienie Jego łaską również Kościoła, wierzących w Chrystusa. „Najważniejszym momentem, który dokonuje się w połowie Jej życia, jest tajemnica wcielenia Syna Bożego [...] z której przyjmuje ciało i staje się człowiekiem" ${ }^{41}$ mocą Ducha Świętego.

Szczególny wkład w zrozumienie relacji Maryi do Ducha Świętego wniósł św. Maksymilian Maria Kolbe, który zastanawiając się nad słowami wypowiedzianymi w Lourdes przez Maryję do Bernadetty Soubirous: „Jestem Niepokalane Poczęcie”, zauważył, że to samookreślenie się Maryi wskazuje na podobieństwo tytułu, jakim Bóg określił siebie na górze Horeb wobec Mojżesza: „Jestem, który Jestem” (Wj 3,14) ${ }^{42}$.

Maksymilian Kolbe określił Trzecią Osobę Boską, owoc nieustającej miłości Ojca i Syna, jako Niepokalane Poczęcie miłości niestworzonej, wiecznej i nieskończonej, a zatem archetyp każdego innego poczęcia stworzonego. Maryja, niepokalana od momentu poczęcia, jest natomiast Niepokalanym Poczęciem stworzonym, które najbardziej ze wszystkich stworzeń jest podobne do Ducha Świętego ${ }^{43}$. Jest Ona zjednoczona w niewypo-

40 Por. L. Scheffczyk, Maryja. Matka i Towarzyszka Chrystusa, s. 143.

${ }^{41}$ Tamże, s. 145; J. Bujak, Trynitarne i antropologiczne aspekty mariologii włoskiej, s. 209-211.

42 Por. Oddanie się Matce Bożej w nauce bt. Maksymiliana Marii, „Ateneum Kapłańskie" 77 (1971) 377, s. 425; J. Bolewski, Miłość i mądrość a Niepokalane Poczęcie, s. 192-193; E. Piacentini, Nuovo corso sistematico di mariologia sub luce Immaculatae, Roma 2002, s. 66-68.

43 Por. L. Bonarrigo, Maria Sposa dello Spirito Santo nella teologia contemporanea, Lugano-Siena 2018, s. 232-233; S. De Fiores, Immacolata (1986), s. 697; P. Liszka, Niepokalane Poczęcie Maryi jako stworzenie „nowego 
wiedziany sposób z Duchem Świętym, będąc Jego Oblubienicą w najwyższym znaczeniu tego słowa, dlatego przysługuje Jej imię Ducha Przenajświętszego, czyli Niepokalane Poczęcie, jak imię małżonka oblubienicy. Niepojęty charakter tej oblubieńczej jedności sprawia, że św. Maksymilian Maria Kolbe określa Niepokalaną „niemal wcieleniem Ducha Świętego”, Paraklet jest bowiem jedyną i całkowitą miłością Dziewicy, dlatego może w Niej uczynić to, co tylko Bóg może sprawić: zrodzenie Chrystusa i chrześcijan. Jedność Ducha Świętego i Maryi jest tak doskonała, że Ten działa w świecie wyłącznie za Jej pośrednictwem. Jest Ona Pośredniczką wszelkich łask Ducha Świętego. Trzecia Osoba Boska działa wyłącznie za pośrednictwem Niepokalanej, swej Oblubienicy, jak pisze Kolbe ${ }^{44}$.

\subsection{Wzrastanie Maryi w łasce zjednoczenia z Bogiem}

Deynira Flores zastanawia się, jak wyglądało życie duchowe Maryi, która jest Niepokalanym Poczęciem, stworzeniem całkowicie i trwale przekształconym przez Bożą łaskę. W poszukiwaniu odpowiedzi na to pytanie autorka sięga do nauczania św. Jana od Krzyża na temat zjednoczenia z Bogiem zawartego w dziele Droga na Górę Karmel, gdzie można przeczytać, że Bóg podniósł Maryję od samego początku Jej istnienia do stanu przemieniającego zjednoczenia. „Do Jej duszy nie przeniknęła żadna forma jakiegoś stworzenia i nigdy nią nie powodowała. Jej poruszenia pochodziły zawsze z działania Ducha Świętego" ${ }^{\prime 5}$.

człowieka" na obraz i podobieństwo Boga Trójjedynego, w: Misterium Niepokalanego Poczęcia Najświętszej Maryi Panny, s. 81.

${ }^{44}$ Por. M.M. Kolbe, Wybór pism, red. J.R. Bar, Warszawa 1973, s. 591, 584; J. Bujak, Trynitarne i antropologiczne aspekty mariologii włoskiej, s. 212-214.

45 Jan od Krzyża, Dzieła, t. I: Droga na Górę Karmel - Noc ciemna, tłum. B. Smyrak, Kraków 1975, s. 269; D. Flores, Mary, the Virgin „Completely and Permanently Transformed by God's Grace", s. 53. 
Nie jest tak, że Maryja dopiero w pewnym momencie swojego życia osiągnęła stan przemieniającej jedności, choćby był on doskonalszy w porównaniu z innymi ludźmi. Święty Jan od Krzyża jasno mówi, że „od początku” swojego życia była Ona wyniesiona przez Boga do stanu, który inni święci osiągają jako swój najwyższy cel w pewnym momencie swej egzystencji, dlatego nie musiała przechodzić przez proces czyszczenia, przez „noce”. Była „cała czysta” od początku. Rozpoczęła swoją pielgrzymkę w wierze od samego szczytu.

W związku z tym rodzi się pytanie: czy oznacza to, że Maryja nie doświadczała postępu w życiu duchowym? Będąc od momentu Niepokalanego Poczęcia już w stanie jedności z Bogiem, Jej życie duchowe było „statyczne”, bez wzrastania? Odpowiedź brzmi, że z pewnością wzrastała Ona w ciągu całego swojego życia w łasce i miłości. Potwierdza to doktryna św. Jana od Krzyża, który pisze, że „Jej poruszenia pochodziły zawsze od Ducha Świętego" ${ }^{\prime 6}$. Zatem Jej życie w łasce i miłości musiało wzrastać w każdym akcie Jej istnienia ${ }^{47}$.

W Żywym płomieniu miłości hiszpański mistyk uczy, że chociaż przemiana w Boga jest najwyższym stopniem doskonałości, który można osiągnąć w tym życiu, to można mówić o wzrastaniu w głębszej i gorętszej miłości również w stanie zjednoczenia przemieniającego $^{48}$. Stan ten zostaje osiągnięty wtedy, gdy miłość staje się doskonałą, uczy hiszpański mistyk. Maryja była

46 Jan od Krzyża, Dzieła, t. I: Droga na Górę Karmel - Noc ciemna, s. 269.

47 Por. D. Flores, Mary, the Virgin „Completely and Permanently Transformed by God's Grace", s. 55.

48 Por. Jan od Krzyża, Dzieła, t. II: Pieśń duchowa - Żywy płomień miłości - Dzieła pomniejsze, tłum. B. Smyrak, Kraków 1975, s. 236: „I chociaż w strofach poprzednio objaśnionych mówiliśmy już o najwyższym stanie doskonałości, do jakiego można dojść w tym życiu, czyli o przeobrażeniu w Boga, to jednak te strofy mówią o bardziej jeszcze udoskonalonej i utrwalonej miłości, w tym samym stanie przeobrażenia. Choć bowiem jest prawdą, że to, o czym jedne i drugie mówią, jest tym samym stanem przeobrażenia i że jako w takim nie można już dalej po- 
w kondycji jedności „od początku”; oznacza to, że miłość Jej Niepokalanego Serca była doskonała od zarania Jej życia. Od pierwszego momentu Jej egzystencji „należy Ona do Chrystusa, ma udział w zbawczej łasce uświęcającej oraz w tej miłości, która swój początek znajduje w «Umiłowanym», w Synu Ojca Przedwiecznego, który poprzez Wcielenie stał się Jej rodzonym Synem"49. Jeśli miłość ta może nieustannie rosnąć, można jedynie podziwiać intensywność i doskonałość tej miłości przy końcu życia Maryi, kiedy Syn wziął Jej ciało i duszę do nieba. Trójjedyny Bóg udzielił całkowicie Matce Jezusa siebie samego od momentu, w którym Ją stworzył, całą czystą i piękną, a Ona poddała samą siebie całkowicie Bogu od pierwszego momentu, rosnąc coraz bardziej w miłości do Niego. Zamieszkanie Przenajświętszej Trójcy osiąga najwyższy stopień doskonałości na ziemi wtedy, kiedy dusza osiąga stan zjednoczenia przemieniającego, Maryja zaś zawsze była w tym stanie ${ }^{50}$.

\section{Niepokalana wzorem wiary wypróbowanej w cierpieniu}

Maryja mimo łaski niepokalanego poczęcia i ścisłego zjednoczenia z Bogiem w Trójcy Świętej idzie przez życie drogą wiary. Katechizm Kościoła katolickiego uczy, że „Dziewica Maryja urzeczywistnia w sposób najdoskonalszy posłuszeństwo wiary [...]. $\mathrm{Z}$ powodu tej wiary wszystkie pokolenia będą Ją nazywały błogosławioną" (KKK 148; por. KKK 273).

Wiara Maryi nie jest jednak wyłącznie Jej zasługą, ale wynika z łaski Bożej, która Ją przeniknęła i uświęciła od chwili Poczęcia,

stąpić - to jednak z biegiem czasu i w miarę ćwiczenia się można o wiele więcej utrwalić się i ugruntować w miłości".

49 Jan Paweł II, Encyklika Redemptoris Mater nr 10.

50 Por. D. Flores, Mary, the Virgin "Completely and Permanently Transformed by God's Grace", s. 56. 
czyniąc z Niej Niepokalanie Poczętą: „W chwili Zwiastowania anioł Gabriel pozdrawia Ją jako «pełną łaski» (Łk 1,28). Istotnie, by móc dać dobrowolne przyzwolenie wiary na zapowiedź swego powołania, było konieczne, aby Maryja była całkowicie przeniknięta przez łaskę Bożą" (KKK 490).

Wiara Maryi nie była jednak pozbawiona trudności i krzyża, była wiarą z jednej strony doskonałą, z drugiej zaś wzrastającą i wiążącą się z doświadczeniem ciemności wiary. Sobór Watykański II w Konstytucji dogmatycznej o Kościele Lumen gentium uczy, że „Błogosławiona Dziewica szła naprzód w pielgrzymce wiary i utrzymała wiernie swe zjednoczenie $z$ Synem aż do krzyża, przy którym nie bez postanowienia Bożego stanęła (por. J 19,25), najgłębiej ze swym Jednorodzonym współcierpiała i z ofiarą Jego złączyła się matczynym duchem, z miłością godząc się, aby doznała ofiarniczego wyniszczenia żertwa z Niej narodzona, a wreszcie przez tegoż Jezusa Chrystusa, umierającego na krzyżu oddana została jako matka uczniowi tymi słowy: «Niewiasto, oto syn twój» (por. J 19,26-27)" (LG 58).

$\mathrm{Na}$ temat ciemności wiary, których doświadczała Maryja w czasie swego itinerarium, ziemskiej pielgrzymki, pisał Jan Paweł II w encyklice Redemptoris Mater (dalej RM), gdzie wiarę Maryi porównywał do wiary Abrahama: jedna i druga wypróbowana jest w ogniu doświadczeń, jednak wiara Maryi jest doskonalsza od Abrahamowej. Życie Maryi papież określa jako „swoisty trud serca, jaki związany jest z «ciemną nocą wiary» - używając słów św. Jana od Krzyża - jakby z «zasłoną», poprzez którą wypada przybliżać się do Niewidzialnego i obcować $\mathrm{z}$ tajemnicą. W taki też sposób Maryja przez wiele lat obcuje z tajemnicą swego Syna i idzie naprzód w swojej pielgrzymce wiary, w miarę jak Jezus «czynił postępy w mądrości [...] i w łasce u Boga i u ludzi» (Łk 2,52)" (RM 17e) $)^{51}$.

${ }^{51}$ Por. T. Siudy, Wiara - „jakby klucz” do prawdy o Maryi, w: Jan Paweł II, Matka Odkupiciela. Tekst i komentarze, red. S.C. Napiórkowski, Lublin 1993, s. 71-72, gdzie polski mariolog zauważa, że papież, opisując wiarę 
Jej cierpienie było jeszcze jednym przejawem współpracy z Synem w dziele Odkupienia - jako Jego najwierniejsza i najbliższa socia cierpiała w zastępstwie całej ludzkości. Zgodnie z Bożą ekonomią zbawienia, było konieczne, by Maryja cierpiała bardziej niż jakikolwiek inny człowiek dla wypełnienia swojej misji Matki Odkupiciela i wszystkich odkupionych ${ }^{52}$.

Maryja, zachowana od grzechu pierworodnego i pożądliwości, będąc w relacji z Trójcą Świętą jako Córka Ojca, Matka Syna i Oblubienica Ducha Świętego, była wolna od każdego grzechu, ale podobnie jak Chrystus była poddana ograniczeniom ludzkiej natury, ponieważ nie oznaczają one niedoskonałości moralnej ${ }^{53}$. Maryja nie cierpiała w wyniku zerwania relacji z Bogiem przez grzech, nie był Jej udziałem debitum peccati, dług grzechowy ${ }^{54}$.

Maryi, „posługuje się charakterystycznymi określeniami, takimi jak: «trud serca», «noc wiary», czy też «kenoza wiary», co przydaje temu pielgrzymowaniu realizmu ustawicznej konfrontacji ze słowem Bożym i wzrastającego przylgnięcia do tajemnicy Syna, w miarę odsłaniania się kolejnych aspektów Jego osoby i Jego misji”; A. Riches, Deconstructing the Linearity of Grace: the Risk and reflexive Paradox of Mary's Immaculate Fiat, „International Journal of Systematic Theology” 10 (2008), s. 183-184. Według kanadyjskiego teologa w fiat zwiastowania wypełniło się w Maryi Abrahamowe „Oto jestem”. Wtedy również Maryja wkracza wraz z Jej Synem w godzinę Jego ofiary, której góra Moria była tylko zapowiedzią. Fiat Maryi przewyższyło wszystkie wcześniejsze „Oto jestem” postaci Starego Testamentu, ponieważ jest ono „pełne łaski”, jest ono odpowiedzią w pełni odkupionego stworzenia, wolnego od wszelkiej winy grzechu. Czystość stworzonego TAK Dziewicy Maryi odpowiada boskiemu niestworzonemu TAK Syna Bożego. Fiat mihi jest również odpowiedzią na fiat lux Stwórcy (Rdz 1,3).

52 Por. D. Flores, Mary, the Virgin „Completely and Permanently Transformed by God's Grace”, s. 67-68; J. Bujak, Maryja - przewodniczka w pielgrzymce wiary, „Rocznik Skrzatuski” 2 (2014), s. 19-36.

53 Por. R. Coggi, Trattato di mariologia, s. 173.

54 Por. D. Mastalska, Niepokalane Poczęcie a cierpienie Maryi, w: Tota pulchra es Maria, s. 309, 325 nn.; W. Wołyniec, Blask misterium Niepokalanego Poczęcia w życiu Maryi i Kościoła, w: Misterium Niepokalanego Poczęcia Najświętszej Maryi Panny, s. 101-104. Wołyniec podkreśla, że Maryja, będąc 
Jednak „Pięćdziesiątnica stworzenia, która w Maryi osiągnęła swój szczyt, obejmowała jej osobę, a nie naturę [...] jej ciało pochodzi od Joachima i Anny, i dlatego dotyczą go konsekwencje upadku Adama. Ciało Maryi nie jest jak w przypadku Chrystusa stworzone w Annie przez Ducha Świętego", podkreśla Bogdan Ferdek. Maryja odczuwała w swoim ciele „słabości będące konsekwencją grzechu pierworodnego, nie była w lepszej sytuacji od Chrystusa, który przybrat sobie dobrowolnie braki ciała. Nie jest osobą grzeszną, ale dotykają ją konsekwencje grzechu Adama"55.

\section{Zakończenie}

Relacja łaski i natury w Maryi wiąże się przynajmniej z trzema kwestiami, które zostały poruszone w artykule. Pierwsza to temat łaski i natury, stworzenia i zbawienia, który w XX wieku ponownie pojawił się $\mathrm{w}$ centrum zainteresowania za sprawą ruchu la nouvelle théologie Henriego de Lubaca, który wystąpił przeciw neotomistycznej ortodoksji, zarzucając jej, że oddziela łaskę od

wolną od grzechu pierworodnego, nigdy nie podlegała szatanowi, jednak uczestnicząc w dziele zbawczym Chrystusa, była wystawiona na pokusy podobnie jak sprawiedliwy Hiob. Pokusy te były związane z zagrożeniem życia Jezusa i utratą domu w wyniku ucieczki do Egiptu, odchodzeniem Syna, wpierw 12-letniego w świątyni jerozolimskiej, następnie w czasie Jego publicznego nauczania i wreszcie z powodu śmierci krzyżowej. Jednak Maryja wychodziła ze wszystkich tych prób zwycięsko, dzięki zgadzaniu się z wolą Bożą; H. Wejman, Znaczenie proklamacji dogmatu o Niepokalanym Poczęciu NMP dla życia duchowego człowieka, w: Misterium Niepokalanego Poczęcia Najświętszej Maryi Panny, s. 36.

55 B. Ferdek, Niepokalane Poczęcie jako misterium Pięćdziesiątnicy, w: Misterium Niepokalanego Poczęcia Najświętszej Maryi Panny, s. 111-112; E. Epsen, Why God Had to Have an Immaculate Mother, „New Blackfriars” 97 (2016), s. 574. Autor stwierdza, że Maryja, tak jak Jej Syn, nie podlegała naturalnej śmierci. Chrystus umarł z powodu grzechów innych ludzi, którym ta śmierć przyniosła zbawienie. 
natury. Kluczem do rozwiązania tej kwestii jest Niepokalane Poczęcie, które ukazuje ich jedność w osobie Maryi, podkreśla Alice E. Wood ${ }^{56}$.

Drugim wymiarem Niepokalanego Poczęcia jest relacja Maryi do Trójcy Świętej. Emanuele Testa zauważa, że w dziejach chrześcijaństwa pojawiały się różne błędne opinie na temat Maryi: dla Żydów była Ona prostytutką, która zgrzeszyła z rzymskim żołnierzem. Dla Ebonitów - zwyczajną żoną zwyczajnego rzemieślnika o imieniu Józef; tak samo uważają Edward Schillebeeckx i Hans Küng. Natomiast dla Ariusza i Apolinarego Maryja była półboginią, matką boskiego Bohatera; dla kolyrydian - postacią wręcz niebiańską, którą należało adorować. Ojcowie Soboru Watykańskiego w Lumen gentium (52-69) odnaleźli prawdziwy klucz do mariologii, ten sam, którego używał pierwszy Kościół w Jerozolimie, który widział Maryję w odniesieniu do Trójcy Świętej. Jest to odniesienie ważne dla całej historii zbawienia i dla wszystkich zbawionych, zależne od zbawczego planu Trójcy Świętej i jedynego Pośrednika ${ }^{57}$.

Trzecim aspektem poruszanym $\mathrm{w}$ artykule jest relacja Maryi do Jej dzieci, do wierzących w Chrystusa, dla których jest Ona Matką, ale również wzorem do naśladowania ze względu na swoją niezachwianą wiarę.

Te trzy wymiary łączą się w Niepokalanie Poczętej, która dzięki łasce Bożej nosi w sobie odnowiony imago Dei i imago Christi, jest nową Ewą, „dziewiczą ziemią”, a zarazem jest podobna do człowieka poprzez wiarę wypróbowaną w cierpieniu podjętym ze względu na dzieło zbawcze swojego Syna. W Niej natura i łaska na nowo odnalazły swoją harmonię, utraconą przez grzech pierworodny, czego potwierdzeniem jest zarówno niepokalany początek Jej życia, jak i jego zakończenie przez wzięcie do nieba

56 A.E. Wood, Creation and Redemption in the Doctrine of the Immaculate Conception, „Maria” 2 (2002) 2, s. 5-19.

57 Por. E. Testa, Maria terra vergine. Vol. I. I rapporti della Madre di Dio con la SS. Trinità (Sec. I-IX), Jerusalem 1985, s. 63. 
z ciałem i duszą. Obecnie „dzięki swej macierzyńskiej miłości opiekuje się braćmi Syna swego, pielgrzymującymi jeszcze i narażonymi na trudy i niebezpieczeństwa, póki nie zostaną doprowadzeni do szczęśliwej ojczyzny" (LG 62).

\section{Grace and Nature in Mary as the Immaculate Conception}

The article Grace and Nature in Mary as the Immaculate Conception is about the relationship between grace and nature in the person of Mary. In Mary, these two realities have rediscovered their harmonious unity lost by original sin. It is confirmed both by the immaculate beginning of her life and by its ending through the assumption of her body and soul into heaven. The article starts with the development of the Church's faith in the immaculate conception of Mary, culminated in the dogma proclamation done by bl. Pius IX in 1854. Moreover, the biblical foundations of faith were presented. The Church perceives Mary as the New Eve and the personification of the Immaculate Bride of Christ the Church. The Immaculate Mary enjoys a special relationship with the persons of the Holy Trinity. It, however, does not separate her from the members of the Church for whom she is both a mother and a model of faith tried in suffering. 